\title{
Phytoremediation of Lead Contaminated Soil Using Croton (Cordiaeumvariegatum) Plants
}

\section{Lina Herlina ${ }^{1,6^{*}}$, Budi Widianarko ${ }^{2}$, Hartuti Purnaweni ${ }^{3}$, Sudarno Sudarno ${ }^{4}$, Henna Rya Sunoko}

1 Doctoral Program Environmental Sciencesof Diponegoro University, Semarang, Indonesia

2 Faculty of Agricultural Technology of Soegijapranata Catholic University, Semarang, Indonesia

3 Faculty of Social and Political Science of Diponegoro University, Semarang, Indonesia

4 Environmental Engineering Department of Diponegoro University, Semarang, Indonesia

5 Faculty of Medicine of Diponegoro University, Semarang, Indonesia

6 Biology Department of Universitas Negeri Semarang, Indonesia

* Corresponding author's e-mail: linaherlina@mail.unnes.ac.id

\begin{abstract}
The lead contamination of the environment affects the life of organisms, as the quality of the environment influences and determines the quality of living things, both plants and animals. Therefore, remediations need to be taken so that the polluted land could be repurposed for various activities safely. Phytoremediation is a method that employs plants to move, detach, or stabilize pollutants in the form of eitherorganic or inorganic compounds. In this study, the Croton (Codiaeum varigatum) plant was used as a phytoremediator planted in pots. Three pots were observed: $500 \mathrm{mg}$ of $\mathrm{Pb}\left(\mathrm{NO}_{3}\right)_{2}$ was added to the first (T1) pot, $750 \mathrm{mg}$ (T2) of $\mathrm{Pb}\left(\mathrm{NO}_{3}\right)_{2}$ was added up to the second (T2) pot, and no addition to the third (T0) pot. The parameters analyzed included plant biomass, the Pb content in plants, bioaccumulation factors, translocation factors, metal tolerance index, and photosynthetic pigment content. The results showed that $\mathrm{Pb}$ affected all of the analyzed parameters. $\mathrm{Pb}$ causes a decrease in the plant biomass and a downturn in chlorophyll $\mathrm{a}$ and $\mathrm{b}$. The $\mathrm{Pb}$ accumulation in root $>$ stem $>$ leaf. The BAF value $<1$, the $\mathrm{TF}$ value $<1$ and the MTI value ranged $89.73-82.80 \%$.
\end{abstract}

Keywords: phytoremediation, lead, contaminated soil, Codiaeum variegatum

\section{INTRODUCTION}

Environmental pollution is a highlighted issue due to the rapid development of factories built to fulfill human needs. The emergence of these factories has resulted in a myriad of waste, which if not managed well, will damage the environment. Recovery should be carried out so that the contaminated land can be repurposed safely for various activities. In order to achieve this goal, an inexpensive and environmentally friendly management strategy has to be developed, and plants are one of the alternatives.

Heavy metals enter the environment owing to the anthropogenic activities including mining, smelting, ore processing, utilization of agricultural sludge waste, use of pesticides, chemical fertilizers, and fossil fuels (Ali et al., 2013) as well as domestic waste (Kumar, 2014). On the other hand, the natural events that cause the entry of heavy metals involve weathering of the host rock, erosion, and volcanic activity (Wuana \& Okieimen, 2011; Parizanganeh et al., 2012). This residence of heavy metals affects the human health and the environment, due to their high contamination and low solubility. Moreover, some heavy metals are carcinogenic and mutagenic (Sheoran et al., 2011).

Phytoremediation is the process of removing pollutants from contaminated air, water, and 
soil using plants that can accumulate, reduce, or eliminate contaminants. The main advantages of the phytoremediation applications include its rapid growth with high biomass production, affordability (Ali khan adan Sajad, 2013) efficiency, environmental friendliness, (Zhang et al., 2012, Ali et al., 2013) and cost-effectiveness (Ahmadpour et al., 2012).

Lead is the second most hazardous heavy metal after arsenic (USEPA, 2000); it is toxic for animals, humans, plants, and microbes (Zhou et al., 2014). Lead is a non-vital element in the metabolism process and could be poisonous for organisms when absorbed even in a little amount. Lead $(\mathrm{Pb})$ is the primary contaminant as it is spread widely in the environment (Mangkoedihardjo et al., 2008). Its mobility may be increased through the food chain mechanism so that its accumulation in soil and waters will threaten the human health and environment (Khan et al., 2010).

Ornamental plants have a quite high economic value, thus, they are very fascinating to cultivate. In addition to beautifying the surrounding, they could accumulate the heavy metals assembled in the soil. In short, ornamental plants possess various practical applications in the indication and prevention of pollution besides beautifying the environment (Mani et al., 2013).

The utilization of croton (Codiaeum variegatum) as an ornamental plant for phytoremediation is still minimal. Hence, it is necessary to further investigate the potential of croton in accumulating $\mathrm{Pb}$ and toxicity. By studying morphology, physiology, and biochemistry, a conclusion was drawn as a consideration for the use of croton in the remediation of the $\mathrm{Pb}$ metals. In short, the objective of this study was to investigate the accumulation of $\mathrm{Pb}$ by $C$. varigatum, the influence of the $\mathrm{Pb}$ metal on the growth of $C$. varigatum, the impact of $\mathrm{Pb}$ on photosynthetic pigments.

\section{METHODS}

\section{Soil collection and analysis}

The soil was taken from the Gedang Anak Village, Ungaran Timur District Semarang. The samples were excavated from a field using a soil sample ring in a depth of 5-10 cm. The physical and chemical properties of the soil comprised: sand, dust, and clay by $42.55 \%, 45.78 \%$ and $11.67 \%$, pH 6.61, 0.44\% C-organic, P $137.93 \mathrm{mg} / 100 \mathrm{~g}$, $\mathrm{K} 13.23 \mathrm{mg} / 100 \mathrm{~g}$, CEC $16.6 \mathrm{CMO}(+) \cdot \mathrm{kg}^{-1}$, $2.22 \mathrm{~cm} / \mathrm{h}$ permeability, $11.25 \%$ water content, $1 / 18 \mathrm{~g} / \mathrm{cm}^{3}$ soil volume, $2.15 \mathrm{~g} / \mathrm{cm}^{3}$ specific gravity, and $45.12 \%$ porosity with the $\mathrm{Pb}$ content of $27.47 \mathrm{mg} \cdot \mathrm{kg}^{-1}$.

\section{Media and growth conditions}

The dry soil was mixed with vermicompost, then filtered with a $2 \mathrm{~mm}$ sieve. Each pot was loaded with $2000 \mathrm{~g}$ of soil, and a tray was placed under each pot to prevent element loss due to watering. Then, $500 \mathrm{mg}$ and $750 \mathrm{mg}$ of $\mathrm{Pb}\left(\mathrm{NO}_{3}\right)_{2}$ were added to the first and second pot, respectively. The test plants were one month old, had four leaves and about $20-30 \mathrm{~cm}$ in height.

\section{Plant sampling and growth analysis}

The plants were picked after three months of subjection to $\mathrm{Pb}\left(\mathrm{NO}_{3}\right)_{2}$. After harvesting, the fresh weight of roots, stems, and leaves was measured and then dried in an oven at $70^{\circ} \mathrm{C}$ to obtain a sustained dry weight.

\section{Analysis of leadcontent in plants}

During the investigation, $1 \mathrm{~g}$ of the plant sample was placed into a porcelain cup and dried in the furnace at $500^{\circ} \mathrm{C}$ until becoming ash, then crushed until smooth and placed in a glass beaker. Then, $50 \mathrm{ml}$ of distilled water, $5 \mathrm{ml}$ of concentrated $\mathrm{HNO}_{3}$, and $2 \mathrm{ml}$ of concentrated $\mathrm{HCl}$..were added to the crushed plants. The mixture was heated on a hot plate for 30 minutes. After being chilled, distilled water was poured upon reaching $50 \mathrm{ml}$. The measurement of the $\mathrm{Pb}$ metal content in plant organs and soil was done using the AAS (Perkin Elmer AAnalyst 400) with a $283.3 \mathrm{~nm}$ wavelength.

\section{Analysis of photosynthetic pigments content}

The photosynthetic pigments were extracted from leaves using $80 \%(\mathrm{v} / \mathrm{v})$ acetone and chlorophyll a, b, The carotenoids content was determined spectrophotometrically at 665,649 and $470 \mathrm{~nm}$ according to (Lichtenthaler 1987) and expressed in $\mathrm{mg} / \mathrm{g}$ fresh weight 


\section{Calculation of bioacumulation factor, translocation factor and metal tolerance index}

The metal tolerance index (MTI) method applied in this study was adopted from Wang et al. (2014). The essential indicators of phytoremediation are translocation factor (TF) and bioaccumulation factors (BAF):

$\mathrm{BAF}=($ plant metal con-

tent) / ( soil metal content .

$\mathrm{TF}=($ metal content in stems $/$

leaves) / (metal content in roots)

MT1 $(\%)=[($ treated plant's bio-

mass $) /($ control's biomass $)] \times 100$

\section{Statisticalanalysis}

Each experiment was performed in triplicate and the data were recorded. All data were analyzed by one-way analysis of variance (ANOVA), using $\mathrm{p} \leq 0.05$ as a significance level and LSD tests conducted for pair-wise comparisons between treatments.

\section{RESULTS AND DISCUSSION}

\section{Effect of lead on plant biomass}

The biomass in roots, stems, and leaves were inversely proportional to the increase in the $\mathrm{Pb}$ concentration (Figure 1). There was a decrease in the root biomass by $7 \%$ and $12 \%$, stems by $17 \%$ and $24 \%$, as well as leaves by $13 \%$ and $26 \%$ during the three-month lead exposure.

The ANOVA test results showed that $\mathrm{Pb}$ affected the biomass of roots, stems, and leaves. The T0 treatments on stems, roots, and leaves were significantly different from $\mathrm{T} 1$ and $\mathrm{T} 2$, yet the $\mathrm{T} 1$ treatments were not remarkably different from the $\mathrm{T} 2$.

\section{Lead content in plants}

$\mathrm{The} \mathrm{Pb}$ content in roots, stems, and leaves of croton during three months of the $\mathrm{Pb}$ exposure with various concentrations is presented in Figure 2. The increased accumulation of $\mathrm{Pb}$ in roots, stems, and leaves was in line with the growth of concentrations. Moreover, the ANOVA test results showed that $\mathrm{Pb}$ affects the accumulation in leaves, stems, and roots. The stems and roots of all treatments differed significantly, but the leaves of treatment T1 and T2 were not considerably contrasting.

\section{Effectof Lead of photosynthetic pigments content}

The chlorophyll $\mathrm{a}$ and $\mathrm{b}$ contents decreased due to the presence of $\mathrm{Pb}$, while the carotenoids content rose (Figure 3). Furthermore, the ANOVA test results indicated that $\mathrm{Pb}$ affected the photosynthetic pigment in croton. The $\mathrm{T} 1$ and $\mathrm{T} 2$ treatments were not significantly diverse in chlorophyll a and carotenoids, but all treatments on chlorophyll b were significantly different.

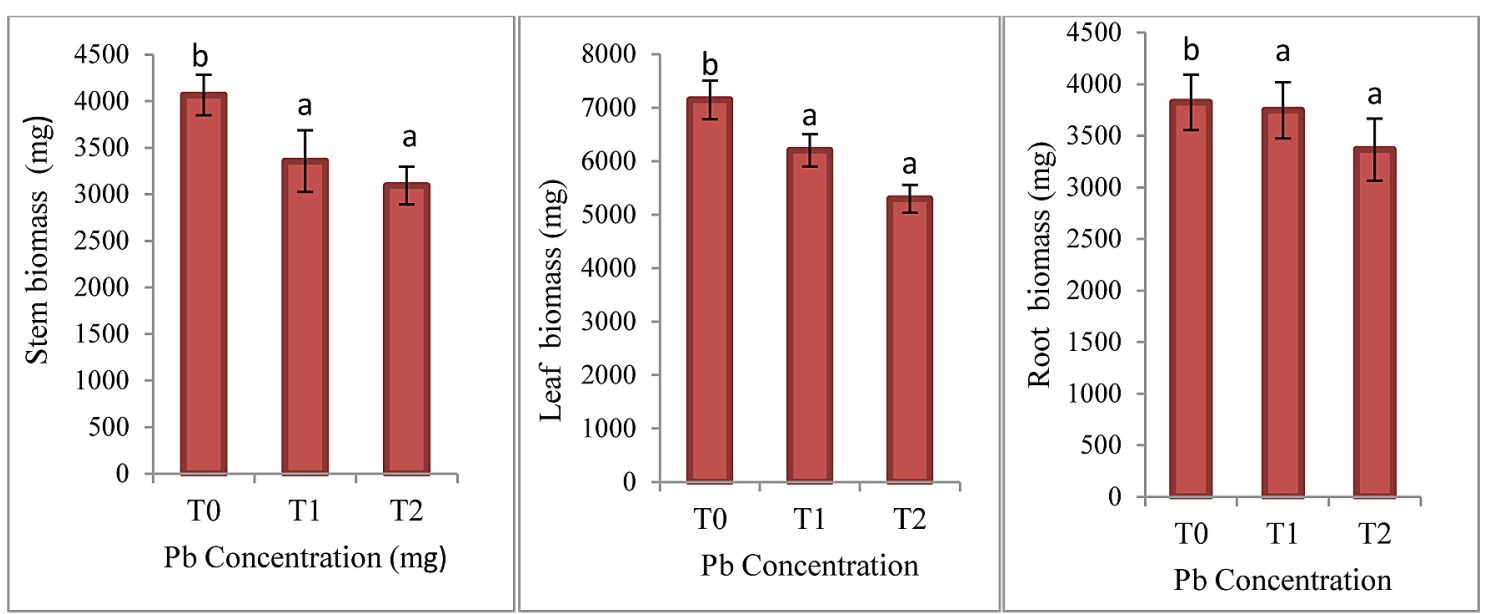

Figure 1. Effect of lead on the biomass of different parts of croton plant (mean \pm SD) at various concentrations of $\mathrm{Pb}$. Different letters indicatesignificant differencesat $\mathrm{p}<0.05$ 


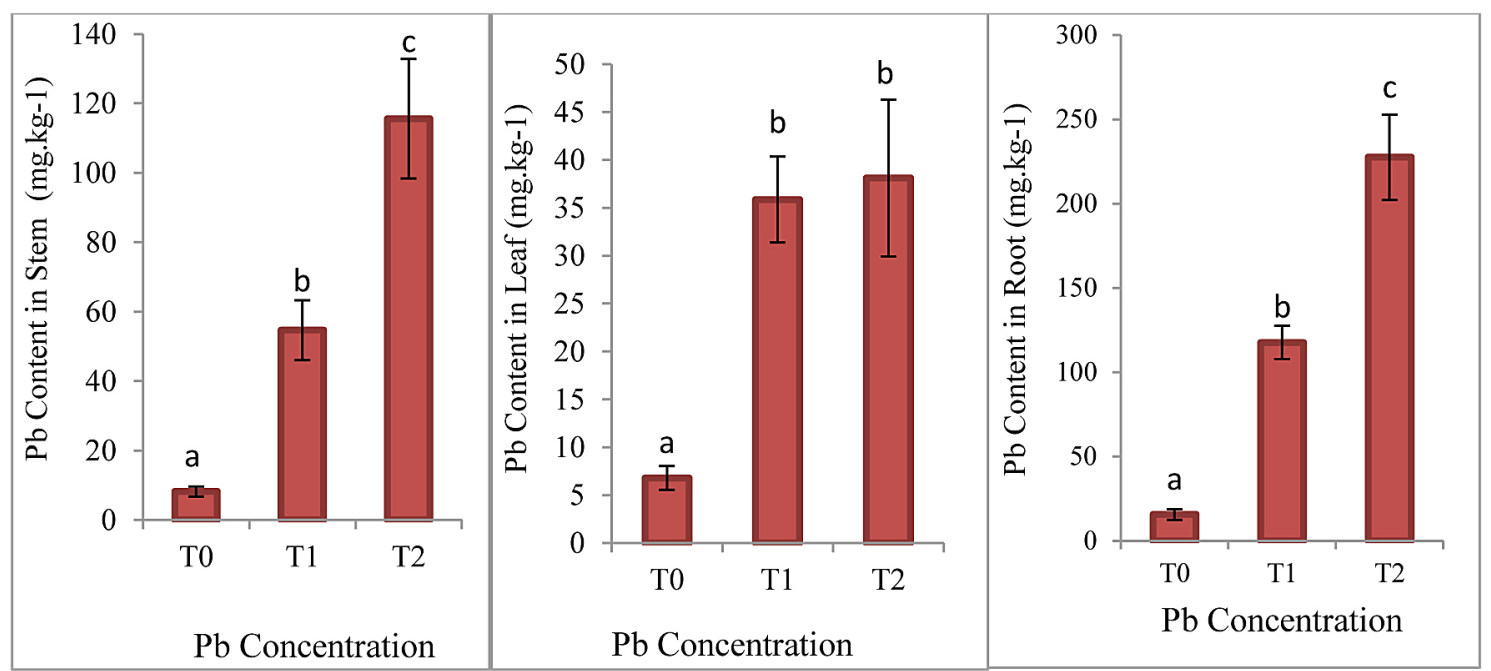

Figure 2. Accumulation of lead content in stem, root, and leaf(mean $\pm \mathrm{SD}$ ) at various concentrations of $\mathrm{Pb}$. Different letters indicatesignificant differencesat $\mathrm{p}<0.05$

Table 1. BAF, TF and MTI values of croton

\begin{tabular}{|c|c|c|c|}
\hline Treatments & BAF & TF & MTI \\
\hline T0 & $1.10 \pm 0.18$ & $0.96 \pm 0.18$ & \\
\hline T1 & $0.63 \pm 0.03$ & $0.79 \pm 0.19$ & $89.73 \pm 4.13$ \\
\hline T2 & $0.46 \pm 0.05$ & $0.68 \pm 0.05$ & $82.80 \pm 3.61$ \\
\hline
\end{tabular}

\section{Bioaccumulation factor (BAF), translocation factor (TF) and metal tolerance index (MTI)}

The BAF, TF, and MTI values decreased as the $\mathrm{Pb}$ concentrations escalated (Table 1). Bioaccumulation factor values in croton ranged from 0.2961 to 1.1019 . If the BAF value less than 1 , the plant is declared phytostabilization, and if the BAF value more than 1, the plant is said to be phytoextraction.
If the TF less than 1 , it means that most heavy metals are accumulated in the root, while if the TF more than1, then the heavy metals are displaced from the root to the canopy. On the other hand, the MTI was above $82.80 \%$, indicating that croton is $\mathrm{Pb}$ tolerant.

\section{DISCUSSION}

This study results revealed a decline in the plant biomass either in roots, stems, or leaves. The decrease of biomass in the lead-contaminated stem, which results in a stunted plant growth, is further explained by Ahmad (2011), stating that the hstem biomass is also influenced by the plant diameter. The plants exposed to lead will experience a decrease in stem diameter, number

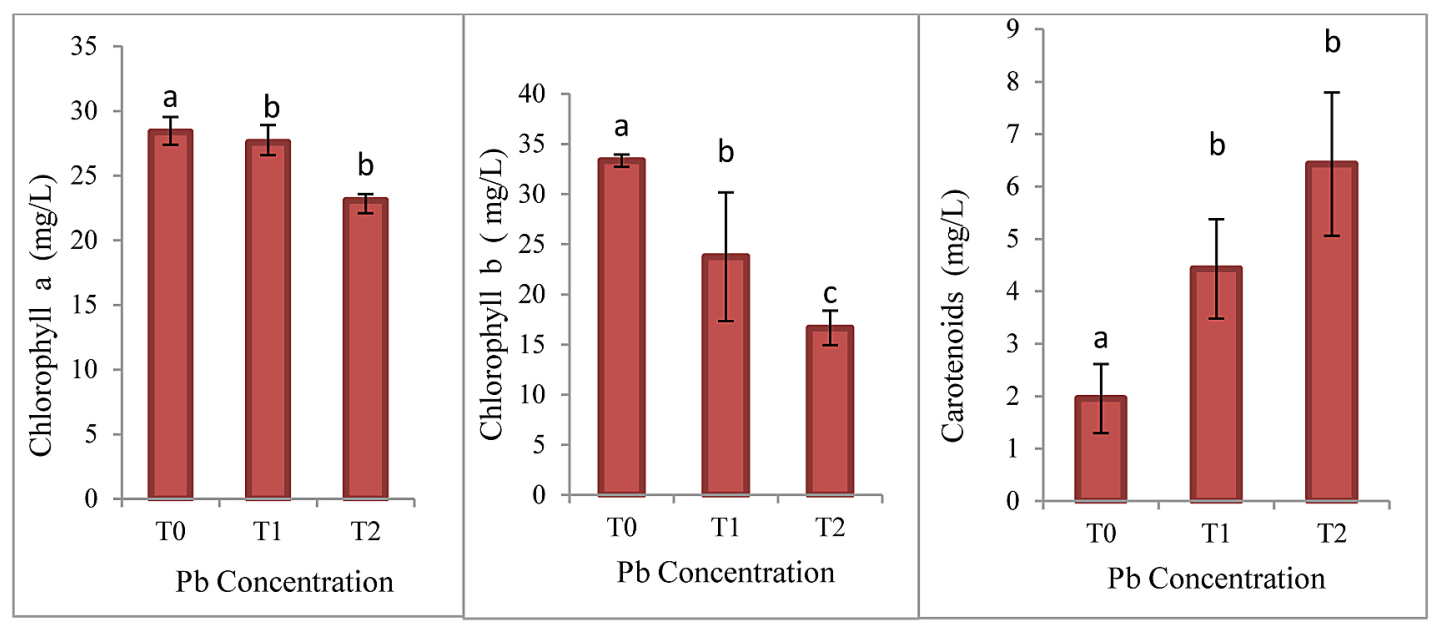

Figure 3. Effect of lead on the photosynthetic pigments content (mean $\pm \mathrm{SD}$ ) at various concentrations of $\mathrm{Pb}$. Different letters indicate significant differencesat $\mathrm{p}<0.05$ 
and diameter of vascular bundles, and size of the stem's storage part. The decline in the stem biomass due to the lead exposure was also explained in the previous research. Tauqeer et al. (2016) reported that there was a decline in the dry and wet weight of Alternanthera bettzickiana on $20 \mathrm{mM}$ lead exposure. The inhibition of growth may be related to the mitosis index retardment by lead and metabolic processes (Liu et al., 2008). Decreasing leaf biomass is a symptom of toxicity to plants, and its forms of toxicity adaptation were detoxification by shedding leaves (Ang et al., 2010). Leaf biomass is influenced by the number of leaves, leaf size, and leaf area (Tauqeer et al., 2016). Lead toxicity causes stunted root extension and root hair development, damage of root system, as well as absorption limitation of water, minerals, and nutrients.

Furthermore, some researchers revealed the inhibition of root growth due to lead toxicity on Elsholtzia argyi (Islam et al., 2018), Sedum alfredii (Gupta et al., 2010). The research by Al-akeel (2016) reported that the administration of $50 \mathrm{ppm}$ lead causes a deplete in the root dry weight of the reed buds. The lead exposure inhibits root growth as a result of nutritional deficiencies and ion imbalances due to lead by ion absorption and lead accumulation (Glesson 2007).

The lead content in roots is greater in than in stems, whereas in stems it is higher than in leaves. $\mathrm{Pb}$ enters the root through mass flow and diffusion, then accumulates in the root, and is translocated into other organs through the transpiration and localization of metals in cells and tissues (Krzeslowska et al., 2010). Endodermis serves as a barrier to the $\mathrm{Pb}$ transfer from the root to the bud. As a result, the $\mathrm{Pb}$ accumulation in the root is greater than the stem or leaf. This is in line with what has been outlined in many studies that the $\mathrm{Pb}$ content in Pisum sativum and Allium sativum's roots is higher than the $\mathrm{Pb}$ content in stems and roots (Malecka et al., 2009; Jiang \& Liu, 2010).

Moreover, the research conducted by Malar et al. (2014) also reported the same thing: that the increase in lead accumulation in stems as lead treatment increased ranging from $100-1000 \mathrm{mg} \cdot \mathrm{kg}^{-1}$ using Eichornia crassipes. The exposure to heavy metals in the stems causes xylem and phloem damage as well as cortex and cambium; this is due to thedeterioration of sclerenchyma tissue and thickening of cell walls in the parenchymal empire area (Abdussalam et al., 2014). The lead exposure to leaves causes chlorosis and necrosis, as lead inhibits enzymes so that metabolic processes, such as respiration and photosynthesis, are disrupted (Kumar et al., 2012).

The plants with TF and BAF values more than1 have the potential to be employed in phytoextraction. Besides, the plants with BAF more than 1 and TF less than 1 have the potential for phytostabilization. Croton has a tolerance index value ranging from $75 \leq 100$, thus, it is categorized as being lead tolerant. Bioaccumulation factor is the ability of plants to accumulate heavy metals, while the ability of plants to translocate heavy metals from roots to other parts is determined through the translocation factor (TF) which is beneficial to decide on the ability of a plant as an accumulator or tolerance (Branzini et al., 2012). The metal tolerance index (MTI) measures the ability of plants to grow at metal concentrations (Zacchini et al., 2009). The plants with a high tolerance can be used in the contaminated areas. On the basis of the tolerance index value, croton is identified as a $\mathrm{Pb}$ tolerant plant. Adaptive plants, when absorbing metals, form reductase enzymes in the roots where the enzymes reduce the metal concentration. The minerals are then transported inside the root membrane (Arisusanti \& Pirwani, 2013).

The accumulation of the $\mathrm{Pb}$ ions in plant tissues has an effect on photosynthetic pigments resulting in a decrease in the chlorophyll levels as metal toxicity can damage chloroplasts and thus interfere with photosynthesis. Inhibition of photosynthesis can occur due to the interference of the metal ions bound to the photosynthetic enzymes and chloroplast membrane (Piotrowska et al., 2009). Photosynthesis in higher plants is more sensitive to the $\mathrm{Pb}$ metal so that it infects the biosynthesis of photosynthetic pigments (Iqbal et al., 2010). Lead can hinder the biosynthesis of chlorophyll by interfering with the absorption of crucial photosynthetic pigment elements, such as potassium, magnesium, calcium, and ions (Piotrowska et al., 2009); also, it can obstruct the action of the enzymes porphobilinogen deaminase and aminolevulinic acid (ALA) dehydration needed in the process of chlorophyll biosynthesis.

\section{CONCLUSION}

Lead $(\mathrm{Pb})$ influences the biomass of roots, stems, and leaves, as well as photosynthetic pigments. The $\mathrm{Pb}$ content in roots $>$ stems $>$ leaves, 
having the value of $\mathrm{BAF}<1$ and $\mathrm{TF}<1$; hence, croton belongs to the excluder group. On the basis of the MTI value, croton is tolerant of $\mathrm{Pb}$ and an accumulator of $\mathrm{Pb}$.

\section{Acknowledgments}

This research was funded by the Doctoral Research Dissertation, Ministry of Research and Technology in 2019.

\section{REFERENCES}

1. Ahmadpour, P., Ahmadpour, F., Mahmud, T.M.M., Abdu, A., Soleimani, M., Tayefeh, H.F. 2012. Phytoremediation of heavy metals: A green technology. African Journal of Biotechnology, 11, 14036-14043.

2. Akeel, K. 2016. Lead Uptake, Accumulation and effects on plant growth of common reed (Pharagmites Australis (Cav) Trin. ex Steudel) plants in hydroponic culture, 3(2), Journal of Advances in Agricultural \& Environmental Eng., 3(2), 2349-1531.

3. Ali, H., Khan, E., Sajad, M.A. 2013. Phytoremediation of heavy metals concepts and applications. Chemosphere, 91, 869-88.

4. Arisusanti R.J. and Purwani K.I. 2013. Pengaruh mikoriza Glomus fasciculatum terhadap akumulasi logam Timbal pada tanaman Dahlia pinnata dalam. Jurnal Sains dan Seni Pomits, 2(2), 2337-3520.

5. Branzini A., González R.S., Zubillaga, M. 2012. Absorption and translocation of copper, zincand chromium by Sesbania virgata. J. Environ. Manag., $102,50-54$.

6. Bu-Olayan and Thomas, B. 2009. Translocation and bioacumalation of trace metal in desert plants of Kuwait governorates. Research Journal of Environmetal Sciences, 3(5), 581-587.

7. Cenkci S., Hakkıcigerci I., Yıldız M., Ozay C., Bozdag A., Terzi H. 2010. Lead contamination reduces chlorophyll biosynthesis and genomic template stability in Brassica rapa L. Environ. Exp. Bot., 67, 467-473.

8. Gupta, A.K., Verma, S.K., Khan, K., Verma, R.K. 2013. Phytoremediation using aromatic plants: A sustainable approach for remediation of heavy metals polluted sites. Environmental Science and Technology, 47(18), 10115-10116.

9. Iqbal N., Masood A., Nazar R., Syeed S., Khan N.A. 2010. Photosynthesis, growth and antioxidant metabolism in mustard (Brassica juncea L.) cultivars differing in cadmium tolerance. Agri. Sci. China, 9, 519-527.

10. Jiang W., Liu D. 2010. Pb-induced cellular defense system in the root meristematic cells of Allium sativum L. BMC Plant Biol., 10, 40.

11. Khan S., Hesham A.E,L., Qiao M., Rehman S., He J.Z. 2010. Effects of $\mathrm{Cd}$ and $\mathrm{Pb}$ on soil microbial community structure and activities. Environ. Sci. Pollut. Res., 17, 288-296.

12. Krzesłowska M., Rabeda I., Basinska A., Lewandowski M., Mellerowicz E.J., A. Napieralska, Samardakiewicz S., Wozny A. 2016. Pectinous cell wall thickenings formation e A common defense strategy of plants to cope with $\mathrm{Pb}$. Environmental Polluion, 214, July, 354-361.

13. Kumar, A., Prasad M., Sytar O. 2012. Lead toxicity, defence strategies and associated indicative biomarkers in Talinum triangulare grown hydroponically. Chemosphere, 89, 1056-1065.

14. Kumar, D.M.C. 2014. Biotechnological advances in bioremediation of heavy metals contaminated ecosystems : an overview with special reference to phytoremediation International Journal of Environmental Science and technology, 843-872

15. Liu, J., Zhou, N.V., Xing, Q., Sun, T., Ma, L.Q., Wang, S, .2008. Growth responses of three ornamental plants to $\mathrm{Cd}$ and $\mathrm{Cd}-\mathrm{Pb}$ stress and their metal accumulation characteristics. Journal of Hazardous Materials, 151(1), 261-267.

16. Malar, S., Shivandra Vikram, S., Favas, P., Perumal, V. 2014. Lead heavy metal toxicity induced changes on growth and antopxidantive anzymes level in watwr hyacinths (Eichhornia crassipes (Mart). Botanical Studies, 55(54), 2-11.

17. Malecka A, Piechalak A, Morkunas I, Tomaszewka B. 2008. Accumulationof lead in root cell of Pisum sativum. Acta Physiol. Plant. 30(5), 629-637.

18. Mangkoedihardjo Sarwoko, and Surahmaida. 2008. Jatropha curcas $\mathrm{L}$. for phytoremediation of lead and cadmium polluted soil. World Applied Sciences Journal, 4(4), 519-522.

19. Mani D., Kumar C., Patel N.K., Sivakumar D. 2012. Enhanced clean-up of lead-contaminated alluvial soil through Chrysanthemum indicum L. Int J. Environ. Sci. Technol.

20. Parizanganeh, A.H., Bijnavand, V., Zamani, A.A. and Hajabolfath, A. 2012. Concentration, distribution and comparison of total and bioavailable heavy metals in top soils of Bonab district in Zanjan Province. Journal of Soil Science, 2, 123-132

21. Piotrowska A., Bagjus A., Zylkiewics B.G., Zambrzycka E., 2009. Changes in Growth, Biochemical Components, and Antioxidant Activity in Aquatic Plant Wolfia Arrhiza (Lemnaceae) Exposed to Cadmium and Lead. Journal Springer Science.

22. Sheoran, V., Sheoran, A., Poonia, P. 2011. Role of hyperaccumulators in phytoextraction of metals from contaminated mining sites: a review. Crit. Rev. Environ. Sci. Technol., 41, 168-214. 
23. Sharma, P., Dubey, R.S. 2005. Lead toxicity in plants. Brazilia . J. Plant Physiology, 17(1), 35-52.

24. Tauqeer H M, Shafaqat A, Muhammad R, Qasim A, Rashid S, Usman I, Rehan A, Muhajid F, Ghulam HA. 2016. Phytoremediation of heavy metal by Alternanthera bettrickiana . Ecotoxicol. Environ.Saf., 126, 138-146.

25. United States Environmental Protection Agency, USEP. 2000. Electrokinetic and phytoremediation in situ treatment of metal-contaminated soil: State-ofthe-Practice. Draft for Final Review. EPA/542/R-00/ XXX. US Environmental Protection Agency, Office of Solid Waste and Emergency Response Technology Innovation Office, Washington DC.

26. Wang C. Tian Y., Wang, X., Geng, J., Jiang, J., Yu, H., Wang, C., 2010. Lead contaminated soil induced oxidative stress, defense response and its indicative biomarkers in roots of Vicia faba seedlings. Ecotoxicology, 19(6), 1130-1139.
27. Wuana R.A. and Okieimen, F.E. 2011. Heavy Metals in Contaminated Soils: A Review of Sources, Chemistry, Risks and Best Available Strategies for Remediation. Communicationsin Soil Science and Plant Analysis, 42, 111-122.

28. Zacchini, M. Pietrini, F. Mugnozza, G. S. Iori, V. Pietrosanti, L. Massacci, A. 2009. Metal tolerance, accumulation and translocation in poplar and willow clones treated with cadmium in hydroponics. Water, Air, and Soil Pollution, 197, No. 1/4, 23-34.

29. Zhang, M.-K., Liu, Z.-Y., Wang, H. 2010. Use of single extraction methods to predict bioavailability of heavy metals in polluted soils to rice. Communications in Soil Science and Plant Analysis, 41(7), 820-831.

30. Zhou, C.F., Y.J. Wang, R. J. Sun, C. Liu, G.P. Fan, W.X. Qin C.C. Li and D.M. Zhou.2014. Inhibition effect of glyphosate on the acute and subacute toxicity of cadmium to earthworm Eisenia fetida. Environ Toxicol Chem., 33, 2351-2357. 